\title{
PRACE NAUKOWE
} Uniwersytetu Ekonomicznego we Wrocławiu

\section{RESEARCH PAPERS of Wrocław University of Economics}

\section{$\mathrm{Nr} 395$}

Finanse i rachunkowość

na rzecz zrównoważonego rozwoju odpowiedzialność, etyka, stabilność finansowa

Tom 1. Finanse

\author{
Redaktorzy naukowi \\ Grażyna Borys \\ Robert Kurek
}


Redakcja wydawnicza: Elżbieta Kożuchowska

Redakcja techniczna: Barbara Łopusiewicz

Korekta: Magdalena Kot

Łamanie: Małgorzata Czupryńska

Projekt okładki: Beata Dębska

Informacje o naborze artykułów i zasadach recenzowania znajdują się na stronie internetowej Wydawnictwa

www.pracenaukowe.ue.wroc.pl

www.wydawnictwo.ue.wroc.pl

Publikacja udostępniona na licencji Creative Commons

Uznanie autorstwa-Użycie niekomercyjne-Bez utworów zależnych 3.0 Polska

(CC BY-NC-ND 3.0 PL)

\section{(c) (i) ()ㅜㅇㅛ}

(C) Copyright by Uniwersytet Ekonomiczny we Wrocławiu

Wrocław 2015

ISSN 1899-3192

e-ISSN 2392-0041

ISBN 978-83-7695-519-3

Wersja pierwotna: publikacja drukowana

Zamówienia na opublikowane prace należy składać na adres:

Wydawnictwo Uniwersytetu Ekonomicznego we Wrocławiu

ul. Komandorska 118/120

53-345 Wrocław

tel./fax 713680 602; e-mail:econbook@ue.wroc.pl

www.ksiegarnia.ue.wroc.pl

Druk i oprawa: TOTEM 


\section{Spis treści}

Wstęp.

Joanna Antczak: Wpływ opłat środowiskowych na wyniki przedsiębiorstwa

Bartosz Bartniczak: Możliwości wykorzystania instrumentów zwrotnych w projektach z zakresu gospodarki odpadami

Sylwia Bożek, Beata Dubiel: Realizacja ryzyka nadzwyczajnego a kompensata jego skutków przez ubezpieczenie

Dorota Burzyńska: Zrównoważona gospodarka wodna na przykładzie metropolii paryskiej

Iwona Dorota Czechowska: Poszukiwanie rzetelności w kontekście kodeksów zawodowych na przykładzie sektora bankowego

Karolina Daszyńska-Żygadło, Bożena Ryszawska: Rola społecznej odpowiedzialności przedsiębiorstw w sustainability transition ....

Anna Dąbkowska: Udział kredytu bankowego w finansowaniu małych i średnich przedsiębiorstw w Polsce i w Niemczech

Leszek Dziawgo, Danuta Dziawgo: Wybrane aspekty CSR na rynku finansowym. Wyniki badań na reprezentatywnej próbie polskiego społeczeństwa

Małgorzata Gorzalczyńska-Koczkodaj: Dysfunkcje systemu sprawozdawczości w jednostkach sektora finansów publicznych

Renata J. Jedlińska: Wpływ gospodarki wirtualnej na gospodarkę realną wybrane zagadnienia

Szymon Kasprowski: Kontrola zasadności pobierania świadczeń w razie choroby i macierzyństwa w polskim systemie ubezpieczeń społecznych w latach 2005-2013

Lidia Kłos: Źródła finansowania ochrony środowiska w Polsce.

Magdalena Kogut-Jaworska: Problem nadmiernego zadłużania się jednostek samorządu terytorialnego w Polsce wobec wyzwań rozwojowych w nowej perspektywie finansowej Unii Europejskiej 2014-2020.

Jan Koleśnik: Postkryzysowe narzędzia analizy nadzorczej a poziom bezpieczeństwa europejskiego systemu bankowego.

Bożena Kolosowska, Agnieszka Huterska: Wykupy obligacji korporacyjnych na rynku Catalyst w latach 2013-2014 - na przykładzie obligacji deweloperskich

Jolanta Korkosz-Gębska: Wspieranie i promocja innowacji ekologicznych na przykładzie województwa lubelskiego 
Andrzej Koza: System kwotowy a zatrudnienie osób niepełnosprawnych w Czechach i w Polsce

Wojciech Krawiec: Inwestowanie zaangażowane społecznie jako forma realizacji koncepcji SRI

Danuta Król: Wybrane instrumenty wspierania rozwoju lokalnego .....

Barbara Kryk: EREŚ jako wyraz rangi środowiska naturalnego w statystyce publicznej

Robert Kurek: Bitcoin a ekonomiczne funkcje pieniądza

Elwira Leśna-Wierszołowicz: Istota nadzoru nad otwartymi funduszami emerytalnymi w Polsce

Irena Lącka: Problemy oceny efektywności podmiotów ekonomii społecznej

Ewa Mazur-Wierzbicka: Nakłady inwestycyjne w ochronie środowiska w Polsce

Jarosław Pawłowski: Ekorating telefonów komórkowych....

Tomasz Potocki: Instytucjonalne uwarunkowania i mechanizmy podnoszenia świadomości finansowej

Adriana Przybyszewska: Zagrożenia i grupy ryzyka współczesnych mikrofinansów

Ewa Spigarska: Opłata za gospodarowanie odpadami jako dochód gminy....

Błażej Suproń: Wpływ elektronicznego systemu poboru opłat drogowych na inwestycje przedsiębiorstw na przykładzie województwa zachodniopomorskiego

Magdalena Swacha-Lech: Problem świadomości finansowej w kontekście gromadzenia oszczędności emerytalnych

Marta Szaja: Realizacja koncepcji zrównoważonego rozwoju a planowanie przestrzenne na szczeblu lokalnym

Marek W. Szewczyk: Przestrzenne zróżnicowanie rozwoju ekonomicznego powiatów województwa lubelskiego

Magdalena Ślebocka: Finansowy aspekt koncepcji rewitalizacji miast w świetle założeń do projektu ustawy o rewitalizacji

Aneta Tylman: Rewitalizacja jako kluczowy aspekt polityki finansowania i rozwoju zrównoważonego miast

Stanisław Wieteska: Emisja dwutlenku węgla przez pojazdy mechaniczne jako element zewnętrznych kosztów transportu drogowego w Polsce.......

Rafał Wilczyński: Znaczenie struktury właścicielskiej spółek publicznych dla rozwoju polskiego rynku kapitałowego w latach 2008-2012

Andrzej Wołoszyn, Romana Głowicka-Wołoszyn: Nierówności dochodowe gospodarstw domowych w Polsce w kontekście zrównoważonego rozwoju

Justyna Zabawa: Ekologiczne wyzwania współczesnej bankowości - przypadek grupy Deutsche Bank

Agnieszka Żołądkiewicz: Ekogospodarka w działalności banków jako przejaw koncepcji społecznej odpowiedzialności biznesu. 


\section{Summaries}

Joanna Antczak: Impact of environmental fees on company's financial results

Bartosz Bartniczak: The ability to use repayable instruments in projects relating to waste management.

Sylwia Bożek, Beata Dubiel: Materialization of the exceptional risk vs. compensation of its effects by insurance

Dorota Burzyńska: Sustainable water management on the example of Paris Metropolis

Iwona Dorota Czechowska: The search for fairness in the context of professional codes on the example of the banking sector.

Karolina Daszyński-Żygadlo, Bożena Ryszawska: The role of corporate social responsibility in sustainability transition .

Anna Dąbkowska: The share of bank credit as sources of SMEs financing in Poland and in Germany

Leszek Dziawgo, Danuta Dziawgo: Selected aspects of CSR in the financial market - survey results on a representative sample of Polish society........

Małgorzata Gorzałczyńska-Koczkodaj: Dysfunctions of the reporting system in public finance sector units

Renata J. Jedlińska: The effect of virtual economy on the real economy selected issues

Szymon Kasprowski: The inspection of legitimate receiving of benefits in case of sickness and maternity in the Polish social insurance system in the years 2005-2013

Lidia Kłos: Sources of financing the environmental protection in Poland......

Magdalena Kogut-Jaworska: Problems of excessive indebtedness of self-government units in Poland in the context of rising challenges for development in the European Union's financial perspective for 2014-2020.....

Jan Koleśnik: Post-crisis tools of the supervisory review process vs. the level of safety of the European banking system

Bożena Kołosowska, Agnieszka Huterska: Corporate bond redemption on the Catalyst market in the years 2013-2014 - the example of the property developers bonds

Jolanta Korkosz-Gębska: Supporting and promotion of eco-innovations based on The Lubelskie Voivodeship

Andrzej Koza: Quota scheme vs. employment of people with disabilities in The Czech Republic and Poland

Wojciech Krawiec: Impact investing as a form of the realization of SRI conception.

Danuta Król: Some local development support tools 
Barbara Kryk: EEEA as evidence for the importance of the natural environment in public statistics

Robert Kurek: Bitcoin vs. economic functions of money

Elwira Leśna-Wierszołowicz: The essence of supervision of open pension funds in Poland

Irena Lącka: Problems of effectiveness evaluation of social economy entities

Ewa Mazur-Wierzbicka: Investment outlays in the environmental protection in Poland

Jarosław Pawłowski: Eco rating of mobile phones

Tomasz Potocki: Institutional conditions and mechanisms which improve the level of financial capabilities

Adriana Przybyszewska: Hazards and risk groups of modern microfinance

Ewa Spigarska: Fee for waste management as an income of a commune......

Blażej Suproń: Influence of electronic road toll collection system on business investments on the example of The West Pomeranian Voivodeship

Magadlena Swacha-Lech: The problem of financial awareness in the context of gathering of retirement savings

Marta Szaja: The realisation of sustainable development concept vs. local-level spatial planning

Marek W. Szewczyk: Spatial diversity of economic development of poviats of The Lubelskie Voivodeship

Magdalena Ślebocka: Financial aspect of the concept of urban renewal in the light of the objectives of the project of Revitalization Act.

Aneta Tylman: Revitalization as the key aspect of the financing and urban sustainable development policy

Stanislaw Wieteska: Carbon dioxide emissions by motor vehicles as part of the external costs of road transport in Poland.

Rafal Wilczyński: Significance of public companies ownership structure for Polish capital market development in the years 2008-2012

Andrzej Woloszyn, Romana Glowicka-Woloszyn: Income inequality of Polish households in the context of sustainable development.

Justyna Zabawa: Environmental challenges of contemporary banking - the case of Deutsche Bank Group

Agnieszka Żolądkiewicz: Ecomanagement in the activities of banks as a manifestation of the concept of corporate social responsibility. 


\begin{tabular}{|c|}
\hline $\begin{array}{l}\text { PRACE NAUKOWE UNIWERSYTETU EKONOMICZNEGO WE WROCLAWIU } \\
\text { RESEARCH PAPERS OF WROCŁAW UNIVERSITY OF ECONOMICS } \\
\text { nr } 395 \cdot 2015\end{array}$ \\
\hline $\begin{array}{l}\text { Finanse i rachunkowość na rzecz zrównoważonego rozwoju - } \\
\text { odpowiedzialność, etyka, stabilność finansowa } \\
\text { Tom 1. Finanse }\end{array}$ \\
\hline $\begin{array}{l}\text { Agnieszka Żołądkiewicz } \\
\text { Uniwersytet Mikołaja Kopernika w Toruniu } \\
\text { e-mail: a_zoladkiewicz@umk.pl }\end{array}$ \\
\hline $\begin{array}{l}\text { EKOGOSPODARKA W DZIALALNOŚCI BANKÓW } \\
\text { JAKO PRZEJAW KONCEPCJI SPOŁECZNEJ } \\
\text { ODPOWIEDZIALNOŚCI BIZNESU }\end{array}$ \\
\hline $\begin{array}{l}\text { ECOMANAGEMENT IN THE ACTIVITIES OF BANKS } \\
\text { AS A MANIFESTATION OF THE CONCEPT } \\
\text { OF CORPORATE SOCIAL RESPONSIBILITY }\end{array}$ \\
\hline
\end{tabular}

DOI: $10.15611 /$ pn.2015.395.39

\begin{abstract}
Streszczenie: Koncepcja CSR (Corporate Social Responsibility - Społeczna Odpowiedzialność Biznesu) jest jedną z najbardziej inspirujących koncepcji współczesnej gospodarki. Jednym z kluczowych obszarów społecznej odpowiedzialności biznesu w bankowości jest ochrona środowiska naturalnego, m.in. występująca w postaci proekologicznej organizacji pracy i procesu gospodarczego. W artykule na przykładzie Banku Millennium SA, ING Banku Śląskiego SA i Banku Zachodniego WBK przeanalizowano faktyczne inicjatywy podejmowane przez sektor bankowy w obszarze ekogospodarki. Wykorzystano dane uzyskane w badaniu ankietowym na reprezentatywnej próbie społeczeństwa polskiego.
\end{abstract}

Słowa kluczowe: społeczna odpowiedzialność biznesu, ekogospodarka, inicjatywy proekologiczne, sektor bankowy.

Summary: The concept of CSR is one of the most inspiring concepts of the modern economy. One of the key areas of corporate social responsibility in banking is to protect the environment, among others occurring in the form of ecological organization of work and the economic process.

Keywords: corporate social responsibility, ecomanagement, environmental initiatives, banking sector.

Wpatrz się głęboko w przyrodę, a wtedy wszystko zrozumiesz

Albert Einstein

\title{
1. Wstęp
}

Społeczna odpowiedzialność biznesu staje się współcześnie jednym z najważniejszych elementów prowadzenia działalności przez różne podmioty gospodarcze, 
w tym również banki. Jednym z kluczowych obszarów społecznej odpowiedzialności biznesu jest ochrona środowiska naturalnego. Inicjatyw na rzecz ochrony środowiska naturalnego w bankowości jest wiele. Interesującym działaniem będącym przejawem koncepcji społecznej odpowiedzialności biznesu jest organizacja pracy i procesu gospodarczego przez banki z uwzględnieniem ochrony środowiska.

Celem artykułu jest prezentacja proekologicznych inicjatyw w działalności banków. Ponadto zwrócono uwagę na wybrane aspekty teoretyczne koncepcji społecznej odpowiedzialności biznesu. W opracowaniu wykorzystano dane uzyskane w badaniu ankietowym na reprezentatywnej próbie społeczeństwa polskiego ${ }^{1}$.

\section{Społeczna odpowiedzialność biznesu}

Podstawowymi czynnikami kształtującymi w sposób bezpośredni ideę społecznej odpowiedzialności były wywodzące się z Biblii zasady: miłosierdzia i włodarstwa. Zasada miłosierdzia nawiązująca do ewangelickiej zasady braterstwa mówiła, że zamożniejsze jednostki społeczeństwa powinny wspomagać opieką biedniejszych i potrzebujących. Współczesne pojmowanie tej zasady sprowadza się m.in. do podejmowania przez przedsiębiorstwa dobroczynnych działań i inicjatyw mających na celu rozwiązywanie problemów społecznych. Zasada włodarstwa głosiła zaś, że przedsiębiorcy i dobrze sytuowani ludzie powinni traktować siebie jako włodarzy, opiekunów majątku powierzonego im przez resztę społeczeństwa. Tym samym jako społeczni zarządcy majątku zobowiązani są do uwzględniania oczekiwań wszystkich tych, którzy są pod wpływem ich decyzji. Obecnie zasada włodarstwa polega na akceptacji współzależności przedsiębiorcy i społeczeństwa oraz na poszanowaniu interesów różnych grup w społeczeństwie [Łukasiewicz-Kamińska 2011].

Zasady miłosierdzia i włodarstwa stały się podstawą dla A. Carnegiego do sformułowania pierwszej wersji doktryny znanej jako ,społeczna odpowiedzialność przedsiębiorstw", opublikowanej w 1899 r. w Ewangelii Bogactwa. Na doktrynę składały się zasady dobroczynności i powierniczości. Zasada dobroczynności odpowiadała zasadzie miłosierdzia, a zasada powierniczości zasadzie włodarstwa [Łukasiewicz-Kamińska 2011].

Rozwój koncepcji Społecznej Odpowiedzialności Biznesu (Corporate Social Responsibility - CSR) jest konsekwencją wydarzeń mających początek w latach 70. XX w. w Stanach Zjednoczonych. Wielkie korporacje przemysłowe, ukierunkowane na maksymalizację zysków, wykorzystując swoją pozycję, podejmowały się licznych negatywnych działan, takich jak: praktyki monopolistyczne, zachowania antyspołeczne, uchylanie się od płacenia podatków. Wykrycie danych praktyk przez społeczeństwo doprowadziło do wzmożonej czujności i większej wrażliwości na działalność korporacji. W konsekwencji powstały liczne grupy nacisku o charakterze ekonomicznym, politycznym oraz lokalnym. Ponadto organizacje konsumenckie

\footnotetext{
${ }^{1}$ Badanie sfinansowane w ramach projektu badawczego pt. „Ekologiczna ewolucja rynku finansowego (EcoFin)", realizowanego z Bankiem Zachodnim WBK w ramach Santander Universidades.
} 
przeciwstawiały się nieetycznym zachowaniom wobec pracowników, kontrahentów oraz odbiorców produktów i usług. Firmy zmuszane były do uwzględniania w swojej działalności aspektów ekologicznych i społecznych. W rezultacie w wielu podmiotach gospodarczych nastąpiła zmiana układu wartości, gdzie obok otoczenia ekonomicznego istotną rolę zaczęło odgrywać otoczenie społeczne. A tradycyjne modele zarządzania zaczęły uwzględniać potrzeby wszystkich interesariuszy przedsiębiorstwa [Łukasiewicz-Kamińska 2011; Plawgo (red.) 2009].

W literaturze przedmiotu można doszukać się licznych definicji pojęcia „społeczna odpowiedzialność biznesu”. Między innymi Bank Światowy określa społeczną odpowiedzialność biznesu jako ideę, która jest: „zobowiązaniem biznesu do przyczyniania się do zrównoważonego rozwoju ekonomicznego przy współpracy zatrudnionych, ich rodzin, lokalnych społeczności oraz całego społeczeństwa, zmierzającym do poprawy jakości życia, co służy zarówno biznesowi, jak i rozwojowi społecznemu" [Bank Światowy 2006].

Szczególną wagę do problematyki CSR przywiązuje Komisja Europejska, która w 2001 r. w Zielonej księdze zdefiniowała społeczną odpowiedzialność biznesu jako koncepcję: „dobrowolnego uwzględniania przez firmę aspektów społecznych i ekologicznych podczas prowadzenia działań handlowych i w kontaktach z interesariuszami" [Green Paper... 2001].

Realizacja koncepcji społecznej odpowiedzialności biznesu w rzeczywistości może obejmować następujące obszary [Bartkowiak 2011]:

- otoczenie rynkowe - dostawcy, odbiorcy, kooperanci, konkurenci,

- otoczenie publiczne - administracja publiczna, instytucje pożytku publicznego, organizacje społeczne, mieszkańcy,

- sfera zatrudnienia - zarządzanie zasobami ludzkimi, rekrutacja, selekcja, system motywacji, wynagrodzenia, rozwiązywanie konfliktów pracowniczych, zwłaszcza w relacjach przełożony-podwładny,

- ochrona środowiska - technologia i organizacja wszelkich działań przedsiębiorstwa związanych z użytkowaniem zasobów środowiska,

- relacje z aktualnymi inwestorami lub potencjalnymi akcjonariuszami.

\section{Ekogospodarka w sektorze bankowym}

Jednym z obszarów społecznej odpowiedzialności biznesu jest ochrona środowiska naturalnego. Działalność podmiotów gospodarczych uwzględniająca ochronę środowiska może mieć istotny wpływ na kreowanie pozytywnego wizerunku przedsiębiorstwa zarówno w społeczeństwie, jak i na rynku. Co ważne, proekologiczne działania dotyczyć mogą nie tylko firm z tzw. eco-biznesu, lecz także innych obszarów gospodarczych, w których w prowadzeniu działalności dobrowolnie uwzględniane są wysokie standardy ekologiczne [Dziawgo 2010a]. Proekologiczne inicjatywy stosowane są również w sektorze bankowym. Ze względu na skalę zaangażowania 
bankowości w inicjatywy proekologiczne stosowany jest termin greening banking zieleniejąca bankowość [Dziawgo 2009].

Inicjatyw na rzecz ochrony środowiska w bankowości jest wiele i zaliczyć można do nich m.in.: uwzględnianie ryzyka ekologicznego jako integralnej części ryzyka kredytowego, organizacja pracy mająca na celu zmniejszenie uciążliwości dla środowiska i ochronę zasobów (ekogospodarka), finansowanie inicjatyw proekologicznych, propagowanie znaczenia ochrony środowiska w działalności marketingowej czy też public relations, oferowanie oraz sprzedaż produktów i usług finansowych powiązanych ze wspieraniem proekologicznych przedsięwzięć gospodarczych i ochroną środowiska [Dziawgo 2007].

W niniejszym opracowaniu zostanie opisane wyłącznie proekologiczne organizowanie pracy i procesu gospodarowania w takich bankach, jak: Bank Millennium SA, Bank Zachodni WBK, ING Bank Śląski SA.

W działalności bankowej dużą uwagę zwraca się na takie zorganizowanie pracy i procesu gospodarowania, aby zaoszczędzić możliwie jak najwięcej zasobów, takich jak: papier, energia elektryczna, energia cieplna, gaz, woda. Ponadto dąży się do ograniczania wytwarzania zanieczyszczeń oraz racjonalnego postępowania z odpadami [Dziawgo 2010b].

Organizacja pracy sprzyjająca ochronie środowiska propagowana $\mathrm{w}$ instytucjach bankowych stała się na tyle popularna, że w stowarzyszeniu VfU opracowano grupę wskaźników EPI (tab. 1). Dane wskaźniki charakteryzują ekologiczny poziom funkcjonowania instytucji bankowej poprzez przeliczenie na jednego zatrudnionego m.in. zużycia energii elektrycznej, energii cieplnej, wody, papieru, a także wytwarzania śmieci oraz emisji gazów cieplarnianych. Brane są pod uwagę również podróże służbowe, a konkretnie wykorzystywane środki lokomocji [Dziawgo 2009].

Tabela 1. Wybrane wskaźniki ekologiczne EPI według VfU

\begin{tabular}{|l|l|l|}
\hline \multicolumn{1}{|c|}{ Wskaźniki ekologiczne } & \multicolumn{1}{c|}{ Miara } & \multicolumn{1}{c|}{ Miara względna } \\
\hline Zużycie energii elektrycznej & $\mathrm{kWh}$ & $\mathrm{kWh} /$ zatrudniony \\
\hline Zużycie energii cieplnej & $\mathrm{kWh}$ & $\mathrm{kWh} / \mathrm{m}^{2}$ \\
\hline Zużycie wody & $\mathrm{m}^{3}$ & $1 /$ zatrudniony/dzień \\
\hline Zużycie papieru & tony & tony/zatrudniony \\
\hline Papier z recyklingu $(\%$ całości) & & $\%$ \\
\hline Odpady & tony & $\mathrm{kg} /$ zatrudniony \\
\hline Podróże służbowe & mln kilometrów & $\mathrm{km} /$ zatrudniony \\
\hline Środki transportu $(\%$ całości) & & $\%$ \\
\hline Emisja $\mathrm{CO}_{2}$ & tony & $\mathrm{kg} /$ zatrudniony \\
\hline
\end{tabular}

Źródło: [Dziawgo 2010]. 
W działalności Banku Millennium SA dostrzec można wiele istotnych działań w zakresie efektywnego wykorzystywania posiadanych zasobów oraz optymalizowania procesu zakupów materiałów potrzebnych do działalności operacyjnej.

Wśród konkretnych działań można wskazać m.in. ograniczanie zużycia papieru dzięki możliwości korzystania przez pracowników banku z tzw. print roomów, jak również przez wprowadzenie domyślnej opcji dwustronnego wydruku oraz skanowania czy też elektronicznego obiegu dokumentów. Mając na celu ograniczenie zużycia papieru, wśród klientów promowane są wyciągi on-line, lokaty internetowe, zawierane są umowy skonsolidowane, ograniczana jest również liczba wydrukowanych dokumentów przekazywanych klientom przez odpowiednie formatowanie tekstu, umieszczanie niektórych dokumentów na stronie bankowej.

Ograniczenie zużycia materiałów plastikowych o 5,45\% w 2013 r. w stosunku do 2012 zostało dokonane m.in. przez: wprowadzenie dyscypliny w zakresie zamawiania butelkowanej wody mineralnej, plastikowych kubeczków i mieszadełek, zainstalowanie uzdatniaczy wody, weryfikowanie zapotrzebowania na plastikowe koperty bezpieczne.

W celu ograniczenia zużycia energii przeprowadzono wymianę oświetlenia w zewnętrznych panelach reklamowych oraz zastosowano wyłączanie oświetlenia o północy. Wprowadzono automatyczny system wyłączania światła po godzinie $18 \mathrm{w}$ budynkach centrali. Wdrożono system monitorowania zużycia energii Verdiem. System ten pozwala obniżyć zużycie energii łącznie o $40 \%$ m.in. przez automatyczne wyłączanie i ponowne uruchamianie komputerów i monitorów w centrali i oddziałach. Dokonana została również wirtualizacja infrastruktury serwerów przez wymianę starej infrastruktury serwerów na wirtualną. W efekcie, poprzez zredukowanie ilości urządzeń informatycznych emitujących ciepło, znacząco zmniejszyło się zużycie energii pobieranej przez klimatyzację. Uzyskano oszczędność szacowaną na 20\% całości zużycia energii w centrum komputerowym.

Ponadto na podstawie danych finansowych sporządzany jest ranking odbiorców energii według jej zużycia. Oddziały o największym wskaźniku zużycia energii są kontrolowane i jeżeli to możliwe, wdrażane są usprawnienia i zalecenia dla firm administrujących budynkami. Również w centrali i oddziałach banku wdrożono zalecenia regulujące działanie urządzeń klimatyzacyjnych, wentylacyjnych i grzewczych zależnie od pór roku i rozkładu dobowego.

Zużycie paliwa przez flotę samochodową Banku Millennium SA w 2013 r. zmniejszyło się o około 2\% w stosunku do roku 2012, w wyniku ograniczenia ilości podróży służbowych poprzez wykorzystanie zdalnych metod komunikacji, takich jak tele- i wideokonferencje, szkolenia e-learningowe.

Nastąpiła również redukcja emisji spalin dzięki sukcesywnej wymianie samochodów służbowych, które mają najwyższe normy emisji spalin, na mniej zanieczyszczające środowisko. We flocie samochodowej Banku Millennium SA znajdują się jedynie samochody z normą Euro 4 (22\%) i Euro 5 (78\%) [Raport CSR 2013, www.bankmillennium.pl]. 
Tabela 2. Zużycie surowców i materiałów w Banku Millennium SA w latach 2012-2013

\begin{tabular}{|c|c|c|c|}
\hline Wyszczególnienie & Zużycie 2013 & $\begin{array}{c}\text { Zużycie } \\
2012\end{array}$ & $\begin{array}{c}\text { Zmiana } \\
2013 / 2012 \\
(\mathrm{w} \%)\end{array}$ \\
\hline Papier i rolki na potrzeby operacyjne (w kg) & 322822 & 369307 & $-12,59$ \\
\hline Koperty (w kg) & 93874 & 101924 & $-7,90$ \\
\hline Artykuły plastikowe (w kg) & 12689 & 13421 & $-5,45$ \\
\hline $\begin{array}{l}\text { Materiały eksploatacyjne do urządzeń drukujących } \\
\text { (w kg) }\end{array}$ & 1677 & 1708 & $-1,79$ \\
\hline Energia elektryczna zakupiona (w kWh) & 30242556 & 31008557 & $-2,47$ \\
\hline Energia cieplna zakupiona (w GJ) & 105841 & 104693 & 1,1 \\
\hline Gaz ziemny $\left(\mathrm{w} \mathrm{m}^{3}\right)$ & 232432 & 200386 & 16 \\
\hline Olej opałowy (w 1) & 69279 & 75818 & $-8,62$ \\
\hline Woda $\left(\mathrm{w} \mathrm{m}^{3}\right.$ ) & 73811 & 85589 & $-13,76$ \\
\hline Paliwo - benzyna (w l) & 491393 & 520737 & $-5,64$ \\
\hline Paliwo - diesel (w l) & 228200 & 210820 & 8,24 \\
\hline Emisja $\mathrm{CO}_{2}$ przez flotę samochodową* $(\mathrm{w} \mathrm{t})$ & 1810 & 1813 & $-0,17$ \\
\hline
\end{tabular}

* przy założeniu, że ilość emisji CO $\mathrm{CO}_{2}$ wynosi: $169 \mathrm{~g} / \mathrm{km}$ - benzyna, $186 \mathrm{~g} / \mathrm{km}$ - diesel.

Źródło: opracowanie własne na podstawie [Raport CSR 2013, www.bankmillennium.pl].

Odpady papierowe, metalowe, drewniane, plastikowe, szklane i elektroniczne powstałe $\mathrm{w}$ wyniku prowadzenia działalności operacyjnej banku przekazywane są do recyklingu lub utylizacji (92\% przekazanych odpadów jest poddawane recyklingowi) [Raport CSR 2013, www.bankmillennium.pl].

Również w ING Banku Śląskim SA dostrzec można wiele istotnych działań w zakresie proekologicznego organizowania pracy i procesu gospodarowania. Wprowadzone rozwiązania technologiczne w banku pozwoliły na ograniczenie zużycia papieru (zakup papieru 2011 r. - 131073 ryzy; w 2012 r. - 119998 ryz), m.in. w segmencie korporacyjnym ograniczono liczbę papierowych przelewów krajowych oraz wyciągów o $87 \%$ w przypadku dużych firm i o $60 \%$ w małych firmach. W przypadku ograniczenia zużycia energii (zużycie energii w 2011 r. - 37286743 kWh, w 2012 r. - $37159229 \mathrm{kWh}$ ) w placówkach montowane są urządzenia energooszczędne, takie jak kompensatory energii czy też zegary astronomiczne, które zainstalowane są już w 90\% lokalizacji i które mają za zadanie sterowanie oświetleniem zgodnie z porami wschodu i zachodu słońca. Ponadto stosowane są wyłącznie żarówki energooszczędne. W ING Banku Śląskim SA zastosowano nowoczesną klimatyzację, która pozwala na redukcję emisji dwutlenku węgla, a zastosowany czynnik chłodzący nie powoduje niszczenia warstwy ozonowej. Flota samochodowa składa się w większości z pojazdów wyposażonych w silniki wysokoprężne (diesel), posiadające normę 
spalin EURO-4 lub EURO-5. Od 2000 r. systematycznie bank zbiera makulaturę, sprzęt elektroniczny, tonery oraz inne odpady biurowe. Sprzęt komputerowy wycofany z użytkowania sprzedawany jest pracownikom lub przekazywany w formie darowizny szkołom i przedszkolom. Pozostały niesprawny sprzęt i inne odpady biurowe utylizują firmy zewnętrzne, które posiadają stosowne zezwolenia [ING sztuka odpowiedzialności...].

Bank Zachodni WBK jest pierwszym bankiem w Polsce, który we współpracy z Fundacją Partnerstwo dla środowiska przystąpił do certyfikacji oddziałów w ramach programu Zielone biuro. W celu ograniczenia energii bank zamiast tradycyjnych świetlówek liniowych zastosował 3- i 4-punktowe białe moduły i zielone taśmy LED, które mogą przynieść oszczędności energii nawet o 50-60\% w stosunku do stosowanych dotychczas tradycyjnych. Oznakowanie placówek zostało też wyposażone we włączniki astronomiczne, dzięki którym można kontrolować porę włączania i wyłączania oświetlenia. Wymiana oznakowania nastąpiła już w około $39 \%$ oddziałów, gdzie pobór prądu w każdym z nich zmniejszył się średnio o około $100 \mathrm{~W}$, tj. o około $30 \%$.

W 2013 r. Bank podpisał umowę najmu powierzchni biurowej w nowym budynku (Atrium 1), który gwarantuje niższe koszty eksploatacyjne i pozwala ograniczyć do minimum negatywny wpływ na środowisko związany z jego użytkowaniem. Jest to nowoczesny, funkcjonalny obiekt biurowy klasy A, zaprojektowany i realizowany w zgodzie z polityką zrównoważonego budownictwa. W budynku zastosowano innowacyjne rozwiązania, które mogą doprowadzić do obniżenia poziomu zużycia energii o co najmniej 50\% w stosunku do krajowych standardów energetycznych. Jednym z tych ulepszeń jest system geotermalnego chłodzenia i ogrzewania. Dzięki podziemnym sondom zimno $\mathrm{z}$ wnętrza ziemi wykorzystywane jest do chłodzenia obiektu w lecie, a ciepło z nagrzanego latem gruntu - do ogrzewania budynku zimą. Istotną cechą systemu jest brak pompy ciepła, co pozwala na oszczędność energii elektrycznej. Prąd potrzebny do funkcjonowania systemu geotermalnego produkowany jest przez panele fotowoltaiczne umieszczone na dachu budynku. Dodatkowo wprowadzono system chłodzenia, tzw. free cooling, wykorzystujący zimne powietrze z zewnątrz. Zużycie energii obniżone zostanie także dzięki oknom z potrójnymi szybami, pozwalającym ograniczyć straty ciepła w zimie, oraz dzięki podwójnej fasadzie z zewnętrznymi żaluzjami, chroniącej budynek przed nadmiernym nagrzewaniem przez promienie słoneczne. Ponadto zostaną wprowadzone nowoczesne technologie pozwalające w znacznym stopniu ograniczyć wykorzystanie wody pitnej do celów innych niż jej pierwotne przeznaczenie. Będzie to m.in. zbiornik na wodę szarą (powstałą po umyciu rąk) i deszczową, która po wstępnym oczyszczeniu wykorzystywana będzie do spłukiwania toalet. W rezultacie przewiduje się, że zużycie wody będzie niższe o niemal $70 \%$ w porównaniu z budynkami referencyjnymi. W sumie oszczędność może wynieść 7370500 litrów wody w ciągu roku [Raport CSR 2013, www.bzwbk.pl]. 
Niepokojące staje się, że pomimo licznych działań proekologicznych prowadzonych przez podmioty gospodarcze, $\mathrm{w}$ tym banki, społeczeństwo nie zauważa takich inicjatyw (tab. $3-21 \%$ żadne, $27 \%$ nie wiem), czy też nawet nie oczekuje takich działań od instytucji finansowych (tab. $4-58 \%$ nie wiem/trudno powiedzieć).

Tabela 3. Rozkład odpowiedzi na pytanie: Proszę wskazać usprawnienia służące ochronie środowiska, które w Pana(i) miejscu pracy wprowadziła firma. Proszę wskazać 3 najważniejsze usprawnienia

\begin{tabular}{|l|c|}
\hline \multicolumn{1}{|c|}{ Odpowiedź } & $\%$ \\
\hline segregacja śmieci/odpadów & 4 \\
\hline żarówki energooszczędne & 2 \\
\hline oszczędność energii & 1 \\
\hline użycie naturalnych nawozów & 21 \\
\hline żadne & 2 \\
\hline inne & 27 \\
\hline nie wiem & 44 \\
\hline nie dotyczy - respondent nie pracuje & \\
\hline Wybrane pojedyncze wskazania & \multicolumn{2}{|l}{} \\
\hline $\begin{array}{l}\text { odnawialne źródła energii, oszczędność wody, zmniejszenie emisji spalin/użycie nowszych } \\
\text { samochodów, oszczędność papieru, opał ekologiczny, filtry na kominach/filtry spalin, } \\
\text { oczyszczalnia ścieków/kanalizacja/usprawnienia w wodociągach }\end{array}$ \\
\hline
\end{tabular}

*Starano się zachować oryginalne sformułowania odpowiedzi

Źródło: wyniki badań uzyskane przez A. Żołądkiewicz w ramach projektu badawczego pt. „Ekologiczna ewolucja rynku finansowego (EcoFin)", realizowanego z Bankiem Zachodnim WBK w ramach Santander Universidades².

Tabela 4. Rozkład odpowiedzi na pytanie: Proszę wskazać 3 najważniejsze konkretne działania, których oczekuje Pan(i) od banków, instytucji finansowych lub spółek giełdowych w kwestii ochrony środowiska naturalnego

\begin{tabular}{|l|c|}
\hline \multicolumn{1}{|c|}{ Odpowiedź } & $\%$ \\
\hline 1 & 2 \\
\hline finansowanie/wsparcie finansowe/sponsoring ochrony środowiska & 15 \\
\hline oczyszczanie/ochrona lasów/rzek, wody/zalesianie & 6 \\
\hline nisko oprocentowane kredyty/niskie ceny usług bankowych & 4 \\
\hline
\end{tabular}

${ }^{2}$ W okresie czerwiec-sierpień 2014 zostało przeprowadzone badanie ankietowe sfinansowane w ramach projektu badawczego pt. „Ekologiczna ewolucja rynku finansowego (EcoFin)”, realizowanego z Bankiem Zachodnim WBK w ramach Santander Universidades. Badanie wykonała na reprezentatywnej próbie polskiego społeczeństwa (próba 1000 respondentów) renomowana agencja badania opinii społecznej GfK Polonia. 
Tabela 4, cd.

\begin{tabular}{|c|c|}
\hline 1 & 2 \\
\hline oszczędność papieru/wyciąg/faktura elektroniczna & 4 \\
\hline uczciwości/ rzetelności/sumienności & 3 \\
\hline oszczędzanie energii elektrycznej/prądu/gazu & 3 \\
\hline ograniczenie emisji spalin/ochrona dziury ozonowej/oczyszczanie powietrza & 2 \\
\hline budowa oczyszczalni ścieków/kanalizacji & 2 \\
\hline utylizacja/segregacja odpadów/likwidacja dzikich wysypisk śmieci & 2 \\
\hline ochrona zwierząt & 1 \\
\hline sadzenie drzew & 1 \\
\hline promocja ochrony środowiska & 1 \\
\hline finansowanie wałów przeciwpowodziowych, pomoc osobom, które straciły dom & 1 \\
\hline inwestowanie w nowe technologie & 1 \\
\hline oszczędność wody & 1 \\
\hline pomoc organizacjom ekologicznym & 1 \\
\hline reklama/sponsorowanie reklam & 1 \\
\hline informacja/zaangażowanie informacyjne/kampania społeczna & 1 \\
\hline nic/żadne/nie oczekuje/banki nie są od tego & 3 \\
\hline inne & 7 \\
\hline nie wiem/trudno powiedzieć & 58 \\
\hline \multicolumn{2}{|l|}{ Wybrane pojedyncze wskazania } \\
\hline \multicolumn{2}{|c|}{$\begin{array}{l}\text { obniżka cen produktów energooszczędnych, brak biurokracji, pomoc w sprzątaniu kraju, panele sło- } \\
\text { neczne, energia odnawialna/wspieranie/finansowanie, budowa ekologicznej infrastruktury, dopłaty } \\
\text { do instalacji solarnych/solarnych ogrzewań, dopłaty, finansowanie do wiatraków/ elektrowni wiatro- } \\
\text { wych, bardziej robić, niż mówić/aby robiły to naprawdę, a nie na pokaz }\end{array}$} \\
\hline
\end{tabular}

* Starano się zachować oryginalne sformułowania odpowiedzi

Źródło: wyniki badań uzyskane przez L. Dziawgo w ramach projektu badawczego pt. „Ekologiczna ewolucja rynku finansowego (EcoFin)”, realizowanego z Bankiem Zachodnim WBK w ramach Santander Universidades.

\section{Zakończenie}

Na podstawie proekologicznych działań trzech banków w zakresie organizacji pracy i procesu gospodarowania można stwierdzić, że idea społecznej odpowiedzialności biznesu w sektorze bankowym jest realizowana na wysokim poziomie. W działalności banków można wskazać liczne przykłady działań proekologicznych, takich jak: ograniczanie zużycia papieru, energii elektrycznej, energii cieplnej, wody, czy też 
dążenie do ograniczania wytwarzania zanieczyszczeń oraz racjonalnego postępowania z odpadami.

Niepokojące jednak staje się to, że społeczeństwo nie ma zbyt dużych oczekiwań od banków w kwestii konkretnych działań na rzecz ochrony środowiska naturalnego. Tym samym można wnioskować, że bank oprócz stosowania konkretnych działań proekologicznych, powinien zwrócić szczególną uwagę na promowanie wśród społeczeństwa inicjatyw proekologicznych, a przede wszystkim prowadzenie kampanii edukacyjnych o tematyce ochrony środowiska naturalnego.

\section{Literatura}

Bank Światowy, Dev Comm SDO, 2006, www.worldbank.org (13.05.2015).

Bartkowiak G., 2011, Społeczna odpowiedzialność biznesu w aspekcie teoretycznym i empirycznym, Difin, Warszawa.

Dziawgo L., 2007, Problemy ochrony środowiska na rynku kapitałowym, „Ekonomia i Środowisko”, nr 1 , s. 113.

Dziawgo L., 2009, Greening banking nowe aspekty konkurencyjności na wspótczesnym rynku bankowym, [w:] Czynniki wzrostu konkurencyjności przedsiębiorstw i regionów, red. M. Haffer, W. Karaszewski, Wydawnictwo Naukowe UMK, Torun.

Dziawgo L., 2010a, Produkty finansowe a ochrona środowiska proekologiczna ewolucja współczesnego rynku finansowego, [w:] W świecie finansów i prawa finansowego. Działalność dydaktyczna profesora Jana Gtuchowskiego, red. B. Kołosowska, P. Prewysz-Kwinto, Wyższa Szkoła Bankowa, Toruń.

Dziawgo L., 2010b, Zielony rynek finansowy. Ekologiczna ewolucja rynku finansowego, PWE, Warszawa.

Green Paper for Promoting a European Framework for Corporate Social Responsibility. COM (2001) 366 final, 2001, Bruksela.

ING sztuka odpowiedzialności. Raport społecznej odpowiedzialności biznesu ING Banku Śląskiego SA 2011-2012, www.ingbank.pl (13.05.2015).

Łukasiewicz-Kamińska A., 2011, Społeczna odpowiedzialność przedsiębiorstwa finansowego, Difin, Warszawa.

Plawgo B. (red.), 2009, Społeczna Odpowiedzialność Biznesu, raport z badań, Wyższa Szkoła Administracji Publicznej im. Stanisława Staszica w Białymstoku, Białystok.

Raport CSR 2013, www.bankmillennium.pl (20.02.2015).

Raport CSR 2013, www.bzwbk.pl (13.05.2015). 